УДК: 7.034(44)

ББК: 85.03

A43

DOI:10.18688/aa166-5-44

Marion Boudon-Machuel, Pascale Charron

\title{
Figurative Art of the Loire Valley through the Prism of the Digital Humanities: ARVIVA and Sculpture 3D Projects
}

The two research projects, ARVIVA and Sculpture 3D, deal with figurative arts created in the Loire Valley during the Renaissance. At the turn of the $15^{\text {th }}$ century, the kings of France, enriched by recent belligerent excursions in Italy, took up residence on the banks of the Loire, thereby stimulating a spate of luxurious artistic production in the region [3]. In addition to the famous Loire Valley châteaux (from Amboise to Chambord), this production included painting in all its forms (panel paintings, miniatures, stained glass). It also included sculpture - the art of funeral monuments par excellence, but also of religious devotion - as well as several other art forms, such as goldsmithery, embroidery, tapestry, and the arts of war, of which today there unfortunately remains next to nothing.

These two projects are based in the CESR (Centre des Etudes Supérieures de la Renaissance/ Centre for Advanced Renaissance Studies) ${ }^{1}$. They form part of a vast interdisciplinary research programme directed by the CESR and entitled Intelligence des Patrimoines (Intelligent Heritage) which involves over 50 research laboratories and 1500 researchers from a wide range of disciplines including "exact" sciences, social sciences, and the humanities ${ }^{2}$. The principal aim of this vast scientific programme is to illustrate the potential of interdisciplinary research to generate new ways of apprehending and understanding heritage sites and objects. This undertaking, supported by the France's Region Centre, is the first of its kind in Europe. The two artistic projects presented here, ARVIVA and Sculpture 3D, are strongly invested with the pioneering spirit of the venture. Both projects issue from the impelling elan, which recently animated regional, national and international studies on artistic production in France at the turn of the $15^{\text {th }}$ century. Within this movement, the Loire Valley occupies a central place. The major importance of Touraine (the region of Tours) as an artistic centre was notably confirmed by the exhibition France 1500: Entre Moyen Âge et Renaissance organised at the Grand-Palais in Paris, in 2010 [8], and then at the Art Institute of Chicago, under the title of Kings, Queens and Courtiers: Art in Early Renaissance France, in 2011 [6, 20]. In Tours itself, the exhibition Tours 1500: Capitale des arts, held in Tours' Museum of Fine Arts in 2012, and enriched by an international scientific colloquium, organised by the CESR in May of the same year, further stressed the region's importance and opened new research perspectives [5].

http://www.cesr.cnrs.fr/ (accessed 27 January 2016).

https://www.intelligencedespatrimoines.fr/ (accessed 27 January 2016). 
The two latter events - the Tours 1500 exhibition and the colloquium - marked, in fact, a decisive turning point in the methods and notions used to apprehend the region's artistic production (Ill. 122). Up to this point, the methodological tools in use were still essentially those developed in the $19^{\text {th }}$ century - that is, tools largely geared towards establishing corpora and fashioned by a sharp consciousness of territorial identity on the part of both historians and historians of art. The methods of attribution developed at the time - necessarily, but with little caution - led to corpora based exclusively around a few famous names of artists. Labels such as "school of the Loire Valley" and "art of the Loire Valley", coined at the time and taken up by following generations, persisted unquestioned throughout the $20^{\text {th }}$ century [12]. The Tours 1500 exhibition and the colloquium which accompanied it took a new look at these fundamentals. On the one hand, they questioned the predominance of Fouquet and his followers with respect to the painting corpora and the almost exclusive monopoly of Michel Colombe in the case of sculpture $[18,16]$. On the other, they vetoed the notion of "regional school" in favour of a more pertinent notion of "artistic centre" or "hearth" - the direct translation of the French term "foyer", which conveys the idea of a radiating or emitting source [9]. As other works, colloquiums and exhibitions have shown that the idea of a dynamic centre corresponds more closely with the territorial reality, characterised by the diffusion of models, techniques and tastes through the circulation of artists, patrons and works [15, 4]. A reality which, if it is to be respected, requires, on the one hand, profoundly re-considering the corpora of identified artists (not just Fouquet and Colombe, but also Poyer, Bourdichon, Regnault, Pacherot and the Juste brothers) and, on the other hand, accepting the anonymous authorship of many high quality works $[17,19]$.

The two projects aim to respond to these new challenges by adopting new digital tools suitable for research in the humanities. Launched in the autumn of 2014, they fully embrace the digital-humanities principle of collaboration by uniting art historians and computer engineers; both provide an ambitious and dynamic working environment in which young $\mathrm{Ph}$. D. and Master's students work alongside experienced researchers; both aim to develop new tools which will permit written, graphic and 3D sources to be exploited in a dynamic and innovative manner.

The ARVIVA's main objective is to model the artistic centre that Touraine constituted between 1460 and 1600. To this end, the archival database, created to prepare for the Tours 1500 exhibition, has been re-thought and entirely re-structured. The initial version of the database was basically a simple Excel table, in which extracts from archival records where organised according to the names and dates of artists and works: these entries facilitated access to data, but they were not interconnected. The ARVIVA database is conceived very differently. Its new structure will eventually permit the kind of open exploitation which characterises the semantic web. The data is organised according to main two poles: artists and works. Primary data is drawn from the archival sources and artistic corpora of Touraine; this is then enriched by extensive bibliographic data. To deal with this bibliographic data efficiently, we are using the online collaborative tool Zotero, which provides the rapidity and elasticity required when working as a team. The database itself, however, has been designed from scratch, in order to cater for highly specific requirements of the ARVIVA project.

In order to apprehend artists and works as completely as possible, the ARVIVA database mobilises as many modes of categorisation as possible. Its real originality, however, lies in the 
use of interactive links between all these different entries. These links enable more precise analytical criteria and innovative querying. One might, for example, wish to know if the role of certain actors in the artistic production of Touraine led to them being identified as artists or not. Moreover, if it did not, then what was the part played by patrons or other people linked to these artists, such as members of their family? In order to reply to this line of questioning, the database is designed to furnish information on both the professional and non-professional relationships of the artists in question: patrons, collaborators, family, and friends. Certain limits are, of course, inevitable. The notion of social status, for example, pertains as it does to the activities and functions of individuals, rather than the relationships between them. Presently, it is queriable for the artists themselves, who constitute the heart of the database, but not for people linked to them. As far as the artists themselves are concerned, the database is able to respond to a wide range of queries, relating to social status, profession, role in collaborative commissions, familial ties, etc. While the aim of the database is not purely prosopographical, prosopography is certainly an important aspect of it, and one that will be further enriched by the eventual integration of the database into the CESR's main portal, which will link it to the centre's other databases, notably those dedicated to sixteenth-century familial and professional networks ${ }^{3}$.

Works of art will be similarly inserted into this system of dynamic networks such as that. Besides being queriable through traditional art-history categories (iconography, place of conservation, date, medium, etc.), they will also be linked to connected fields, thus enabling at once more precise and further-reaching search possibilities. Let us consider, as an example, the context of the commission of the Liget Altarpiece [14] (Loches, Galerie Antonine) (Ill. 123). In the background of the right-hand panel of this tryptic, the patron of this work, Jean Béraud, prior of the Charterhouse of Liget, is portrayed kneeling and praying besides the tomb of Christ. His initials are inscribed beside him, and the date of the commission is painted at the bottom of the left hand panel, representing the Bearing of the Cross. Since the 1990s, the work was attributed to Jean Poyer on the basis of stylistic links with the rest of this artist's corpus that principally consists of illuminated miniatures, dating to the same years, such as Les Heures Briçonnet, conserved in Haarlem, Holland [13, pp. 11-17]. The suppleness of interconnected online data permits this basic information to be obtained instantaneously. It also allows the visual sources of the artist to be queried. Poyer notably drew inspiration from both Fouquet - the Crucifixion is clearly adapted from the Fouquet's version of the theme in the Hours of Etienne Chevalier - and Mantegna. Both the swooning figure of the Virgin, supported by one of the female saints, and the praying figure of John the Evangelist are inspired by Mantegna's engraving of the Entombment ${ }^{4}$, dating from c. 1470 [1, p. 250-251]. Following on from there, database users could either enlarge their investigation on the Liget Altarpiece by branching out via iconographic, chronological, media or typological search options, or alternatively, pursue the direction opened by the first round of results, going on, for instance, to search for all the works of Touraine-based artists inspired by Mantegna.

3 Rivhage http://rihvage.univ-tours.fr De minute en minute, http://www.bvh.univ-tours.fr/index.htm (accessed 27 January 2016).

4 http://mini-site.louvre.fr/mantegna/acc/xmlfr/section_6_0.html (accessed 27 January 2016). 
Other parallels revealed by working with structured online networks of images include those between painting and sculpture. These explicate particularly well the dynamic notion of the artistic "centre" and its superior relevance with respect to the old notion of "school", in terms of both space and time. The sculpture known as the Infant of Jarzé (Ill. 124) (possibly a representation of Saint Cyr as a child) forms, for example, part of a "multi-media" network which extended through Touraine and the Bourbonnais region at the end of the $15^{\text {th }}$ century [7, p. 168-169]. The infant, portrayed standing with a rattle in one hand and a piece of cloth in the other, strongly recalls certain children painted by Jean Fouquet and Jean Hey. The hieratic posture, the simple drapery, falling straight to the feet, the curve of the skull, enclosed by a small bonnet, and the full cheeks are all notable traits of the children in the Saint Anne and the Three Marys from the Hours of Etienne Chevalier ${ }^{5}$ [2, p. 193-217]. The almond-shaped, slightly swollen eyes, the heavy cheeks and thick lips of the Infant of Jarzé also recall the Portrait of the Dauphin Charles Orland painted by Jean $\mathrm{Hey}^{6}$. The sculpture can also be compared with other contemporary sculpted works: the statues of the children of Charles VIII, for example, which grace their joint tomb in the cathedral of Tours (Ill. 125), as well as the angels and spiritelli which accompany them [10, p. 27-31, 89-90], and even certain statues of the Infant Jesus from several Virgin and Child sculptures conserved in the Louvre (Ill. 126). Such comparisons invite a reflection on the representation of infancy - notably royal and divine infancy - in Touraine at the beginning of the Renaissance, as well as on the distinction, sometimes very slight, even deliberately ambiguous, between pure portraiture and images of people or divine beings that were not available to sit as models, such as saints from earlier centuries. Other parallels between painting and sculpture are equally fertile. Jean Bourdichon's famous Great Hours of Anne of Brittany, which dates 1504-1508, contains a number of figures which evoke the crypto-portraits of Pierre de Bourbon, his wife Anne de Beaujeu, and their daughter Suzanne sculpted by Jean Guilhomet (known as Jean de Chartres) and conserved in the Chateau of Chantelle in southern Bourbonnais [11, p. 413]. This family group is again portrayed, this time in paint, but with striking formal echoes with respect to the sculpture, in the famous Moulins Tryptic, which dates the same years. We see here very clearly how the idea of a dynamic artistic centre is manifested by the works themselves. By interconnecting via a wide range of links all the images, contained in the online database, with as many other images as possible, the ARVIVA team aims to reciprocally deepen the understanding of individual works and the multi-formal networks they compose.

Besides opening these exciting new perspectives, digital research tools are on the point of revolutionising our ability to apprehend sculptural objects. Inherently, 3D sculpture is still essentially taught and diffused by using 2D media. PowerPoint enables us to partially counter this problem by displaying several different views of a given work simultaneously. It is, nevertheless, incapable of conveying the real dimensionality of the work. In recent years, much progress has been made in the field of 3D virtual representations, notably where architecture is concerned. Sculpture, being smaller and more detailed, requires a finer quality of rendition, 
and thus represents a greater challenge. However, new tools, capable of meeting this challenge, are starting to appear.

The Sculpture 3D project associates specialists in sculpture and experts in 3D visualisation. The project's principal aim is not to produce an exhaustive 3D virtual corpus of Renaissance Loire-Valley sculpture, but to focus on specific dossiers, which illustrate the different ways digital tools can be used to deepen understanding of these works. The use of augmented reality will allow us to provide privileged views of works that cannot be easily seen in real life, one example being the Infant of Jarzé placed in a high-set niche of an altarpiece. Another example is the Virgin of Blois, which, although it is presented at a spectator-friendly height in the Châteaux of Blois, is again placed in a niche. Therefore, it is impossible to see it from every angle and thus properly appreciate its volume, weight and detail. This piece has been acquired using a 3D scanner device allowing a deep insight into the sculpture details, thanks to a high spatial resolution of acquired 3D points. The wireframe rendering demonstrates the complexity of the obtained triangle mesh, showing the high density of triangles the model is built with (Ill. 127). Thanks to the $3 \mathrm{D}$ visualisation, all its characteristics could be compared with those of other statues of the Virgin and Child which, shaped by the chisels of such artists as Michel Colombe or Guillaume Regnault, contributed to the reputation of the region's sculpture.

The importance of the iconographic theme of the Virgin and Child in the region is, in fact, such that it will soon be the object of an important exhibition organised jointly by the teams of our two research projects: Sculpture 3D and the ARVIVA. Entitled Ceci nest pas une sculpture: Statues de la Vierge et de l'Enfant en Val de Loire en réalité augmentée (This is not a Sculpture: Statues of the Virgin and the Child of the Loire Valley in Augmented Reality), this exhibition will take place at the Museum of Fine Arts in Tours in 2018. By focusing on the pair formed by the Virgin and the Infant Jesus, this excursion into augmented-reality will provide an opportunity to address the multiple questions raised by the representation of infancy. For this reason, the exhibition will accord a privileged place to the Tomb of the Children of Charles VIII. This large funeral monument is one of the major works in the Loire-Valley sculpture corpus. Certainly, it will not be transferred from the cathedral to the museum, but uniquely presented in the form of a virtual 3D clone. The picture shows the textured 3-Dimensional model of the tomb (Ill. 124). This model has been reconstructed from several high-resolution photographs, allowing thus a photorealistic rendering. The reconstruction method we used only relies on these multiple views to evaluate the $3 \mathrm{D}$ position information. This visualisation will enable visitors to appreciate the monument from points of view generally unattainable in a cathedral (from above, for example). The virtual clone will also enable the development of a dynamic mediating programme useful for explaining certain details of the monument. The interface of the $3 \mathrm{D}$ visualisation of this tomb, as well as those of the other works concerned by this research project, is currently the object of intense reflection. A first series of results has already been obtained. It confirms our hope of being able to provide a wide range of visitors with new and dynamic knowledge, when the exhibition opens in 2018.

The visualisation programme undertaken by Sculpture $3 D$ also includes a number of highly ambitious elements, such as the forty or so sculpted scenes of the choir tower of the Cathedral of Chartres, which date variously from the Renaissance to the $18^{\text {th }}$ century and are very little known, even by specialists. The Cultural Affairs Office of France's Region Centre has recent- 
ly decided to restore entirely this veritable reference book of the late-fifteenth to the eighteenth-century sculpture - a project which will extend over several years. Sculpture 3D will create a digital visualisation of the ensemble, based on a panoramic view, as well as $3 \mathrm{D}$ virtual representations of a number of individual heads, hands, clothing, and even some entire statues, such as the group of the High Priest and Jesus Child of the Presentation of Jesus of François Marchand. The photography shows a view of the 3D scan setup of the group of the Chartres choir. The scanning technique, we've employed, consisted in making the sculpture rotate by using a computer-controlled platform device. The smooth rotation move of this device ensures the full coverage of the piece during the 3D acquisition (Ill. 128). Through such visualisations, Sculpture $3 D$ will enable users to virtually grasp manipulate statues, to view them from every angle and at close range, making possible to appreciate the very grain of the material they are made of. To achieve this latter point, the team is working with two scanners in order to produce particularly high-quality images (Ill. 129). The results of the project will provide not only specialists, but also general public with intrinsic knowledge of the works, thereby contributing to deeper understanding of their materiality and history (traces of tools, materials, polychromy, and state of conservation).

In accordance with the fundamental philosophy of the Digital Humanities, both Sculpture $3 D$ and ARVIVA projects aim to make the state-of-the-art special technique accessible to as wide range of public as possible. In order to do this, both projects accord primary importance of developing of search filters and interfaces, which would take into account the diverse motivations, requirements and competence of different users. The new research perspectives offered by digital tools, intelligent databases, and augmented reality will be revealed in full during the exhibition that will take place at the Museum of Fine Arts of Tours in early 2018, and via the online portal on the site of the CESR in the course of the forthcoming year.

Title. Figurative Art of the Loire Valley through the Prism of the Digital Humanities: ARVIVA and Sculpture 3D Projects.

Authors. Marion Boudon-Machuel - Ph. D., professor. Tours François Rabelais University - Centre d'études supérieures de la Renaissance, Rue Néricault-Destouches, 59, B.P. 12050, 37020 Tours Cedex 1, France.marion.boudon-machuel@univ-tours.fr

Pascale Charron - Ph. D., associate professor. Tours François Rabelais University - Centre détudes supérieures de la Renaissance, Rue Néricault-Destouches, 59, B.P. 12050, 37020 Tours Cedex 1, France. pascale.charron@univ-tours.fr

Abstract. At the very beginning of the $16^{\text {th }}$ century, the Loire Valley was the French Royal Court residence and then a center of high level of artistic production (painting, sculpture, jewelry, tapestry, illuminated manuscripts...). In the 1900s, the young discipline of art history focused on this "regional school of artistic production" and defined specific tools for studying it. Such fundamental studies, as that of Paul Vitry on Michel Colombe (Paris, 1901), and the 1904 exhibition on French Primitives, determined two main ways of study: firstly, monographic analysis of the production of important artists, such as Jean Fouquet, Michel Colombe or Jean Bourdichon; secondly, the definitions of notions like "school of the Loire Valley" or "art de la détente". Recent historiography has reconsidered that subject and proposed new lines of reflection. The more dynamic and opened notion of "foyer" has replaced the notion of "regional artistic school", and the anonymous corpus or those of the major masters have been reevaluated (Michel Colombe, Jean Poyer, Master of Claude of France).

The Centre des Etudes Supérieures de la Renaissance is an actual motive of this revival through two programs of research. The ARVIVA project inventories, analyses and evaluates the figurative arts of the Loire Valley within the large period from 1470 to 1600 . The Sculpture $3 D$ project proposes the reconsideration of key masterpieces with the help of augmented reality in order to place new digital tools in service of 
scientific analysis. The first results of these programs are manifold. The enlarged period of study allows better understanding of the evolution of the artistic production. Moreover, deeper archives researches enlighten relationships of artists and donors and draw an interactive social network of Tours during the 1500s.

On that base, this paper focuses on particular examples: Tours, as a capital of luxury, parishes as the center of microhistory of the social network, and recently discovered works of art.

Keywords: the Loire Valley; Renaissance; augmented reality; Digital Humanities; interdisciplinary research.

Название статьи. Искусство долины Луары сквозь призму цифровых методов в гуманитарных науках: проекты ARVIVA и Sculpture 3D.

Сведения об авторах. Будон-Машуэль Марьон - Ph. D., профессор. Университет Тура - Центр исследований Ренессанса (Франция), ул. Нерико-Детуш, 59, Тур, п/я 12050, Франция, 37020. marion. boudon-machuel@univ-tours.fr

Шаррон Паскаль - Ph. D., доцент. Университет Тура - Центр исследований Ренессанса (Франция), ул. Нерико-Детуш, 59, Тур, п/я 12050, Франция, 37020. pascalecharron@free.fr

Аннотация. С начала XVI в. в долине Луары располагалась резиденция французских королей, что предопределило развитие в этом регионе искусств - живописи, скульптуры, ювелирного дела, миниатюры, производства гобеленов. Обратившись к этой теме в начале XX столетия, молодая научная дисциплина «история искусства» сосредоточила внимание на понятии "региональной школы» и определила специфические инструменты ее изучения. Такие основополагающие работы, как исследование Поля Витри, посвященное Мишелю Коломбу (1902), выставка французских примитивов 1904 г. и целый пласт опирающихся на них исследований, определили два подхода, которые будут доминировать в изучении искусства долины Луары на протяжении XX в.: монографическое изучение отдельных мастеров (Жан Фуке, Мишель Коломб, Жан Бурдишон) и определение понятий, таких как «школа долины Луары», art de la détente и др. Современная историография отказывается от этих подходов и предлагает новое направление исследования, предпочитая, в частности, термину «региональная школа» более открытое и динамичное понятие «центра искусства». С этих позиций были переосмыслены корпусы работ анонимных и известных мастеров (таких как Мишель Коломб, Жан Пуайе, Мастер Клод Французский).

Работая в этом ключе, Центр исследований Ренессанса (CESR) запустил две новые исследовательские программы. Целью первого проекта - ARVIVA - является каталогизация, анализ и изучение произведений изобразительного искусства долины Луары в широких хронологических рамках с 1470 по 1600 г. Вторая программа - Sculpture 3D, - привлекая на службу гуманитарным наукам компьютерные технологии, предлагает вновь рассмотреть наиболее значимые памятники с использованием инструментов «дополненной реальности». Уже первые результаты оказались разнообразными и многообещающими. Расширенный хронологический диапазон позволил лучше понять особенности эволюции художественного производства. Более того, в ходе углубленных архивных разысканий были выявлены новые сведения о взаимоотношениях художников и заказчиков, которые способствуют созданию целостной картины сложного переплетения социальных и художественных связей в Туре около 1500 г.

Настоящая статья вводит в научный оборот прежде неизвестные произведения и новые подходы к изучению памятников, а также иллюстрирует на конкретных примерах такие тезисы, как: Тур столица роскоши; приходская церковь - центр микроистории социальных взаимосвязей.

Ключевые слова: долина Луары; Ренессанс; «дополненная реальность»; цифровые технологии в гуманитарных науках; междисциплинарные исследования.

\section{References}

1. Agosti G.; Thiébaut D. (eds.) Mantegna 1431-1506, catalogue d'exposition. Paris, Musée du Louvre Publ., 2008. 480 p. (in French).

2. Avril F. Jean Fouquet. Peintre et enlumineur au XVe siècle, Paris, 2003. 428 p. (in French).

3. De Chancel B.; Charron P.; Girault P.-G.; Guillouët J.-M. (eds.) Tours 1500. Capitale des Arts. Tours, Musée des Beaux-Arts - Paris, Somogy Publ., 2012, 384 p. (in French).

4. Boudon-Machuel M.; Bresc-Bautier G. Enjeux d'une exposition: Le Beau XVI ${ }^{e}$ siècle. Chefs-d'œuvre de la sculpture troyenne. La Sculpture française du XVI siècle. Études et recherches, actes du colloque 
international, 1-2 octobre 2009, Paris, INHA, 3 octobre 2009. Troyes, Conseil Général de l'Aube Marseille, Le Bec en l'air éditions Publ., 2011, pp. 91-104 (in French).

5. Boudon-Machuel M.; Charron P. (eds.) Art et société à Tours au début de la Renaissance, actes du colloque international 10-12 mai 2012, Tours, CESR. Turnhout, Brépols Publ. (in press) (in French).

6. Bresc-Bautier G.; Crépin-Leblond Th.; Taburet-Delahaye E. (eds.) France 1500: entre Moyen Âge et Renaissance, Paris, Galeries nationales, Grand Palais, 6 octobre 2010 - janvier 2011. Paris, RMN Publ., 2010. 400 p. (in French).

7. Cassagnes-Brouquet S. Louis XI ou le mécénat bien tempéré. Rennes, 2007. 270 p. (in French).

8. Chevalier B. Tours ville royale, 1356-1520. Origine et développement d’une capitale à la fin du Moyen Âge. Paris - Louvain, 1975. 343 p. (in French).

9. De Chancel B.; Charron P.; Girault P.-G.; Guillouët J.-M. L' “école de Tours" ou l' "école du Val de Loire" en question. Tours 1500. Capitale des Arts. Tours, Musée des Beaux-Arts - Paris, Somogy Publ., 2012, pp. 37-48 (in French).

10. Droguet V.; Réau M. Th. Tours, décor et mobilier des édifices religieux et publics. Paris, 1993. 240 p. (in French).

11. Gaborit J.-R. Musée du Louvre: Sculpture française 2, Renaissance et Temps modernes. Paris, 1998. 879 p. (in French).

12. Guillouët J.-M. La sculpture du Val de Loire: une école introuvable? 303, arts, recherches, créations, 2003, no. 75, pp. 250-259 (in French).

13. Hofmann M. Jean Poyer: Das Gesamtwerk. Turnhout, Brépols Publ., 2004. 347 p. (in German).

14. Hofmann M. Jean Poyer et Jean Bourdichon: peintres de retables à Tours vers la fin du XVe siècle. L'Europe des retables, actes du colloque du Mans (13-16 octobre 2004), 2007, vol. 1, pp. 190-205 (in French).

15. Laurent Chr.; Riffaud-Longuespé Ph.; Murienne Fr.; Boumaza M. (eds.) Le Beau XVI siècle: chefsd'euvre de la sculpture en Champagne, Troyes, église Saint-Jean-au-Marché, 18 avril - 25 octobre 2009. Paris, 2009. 299 p. (in French).

16. Pradel P. Michel Colombe, le dernier imagier gothique. Paris, Éditions d'histoire et d'art, librairie Plon Publ., 1953. 160 p. (in French).

17. Sterling C. The Master of Claude, Queen of France: A Newly Defined Miniaturist. New York, H. P. Krauss Publ., 1975. 71 p.

18. Vitry P. Michel Colombe et la sculpture française de son temps. Paris, Librairie centrale des Beaux-Arts Publ., 1901. 531 p. (in French).

19. Wieck R. S. Miracles in Miniature. The Art of the Master of Claude de France. New York, The Morgan Library and Museum Publ., 2014. 95 p.

20. Wolff M. (ed.) Kings, Queens, and Courtiers: Art in Early Renaissance France, Art Institute of Chicago, $27^{\text {th }}$ February - 30 $0^{\text {th }}$ May 2011. Chicago - New Haven, 2011. 208 p. 


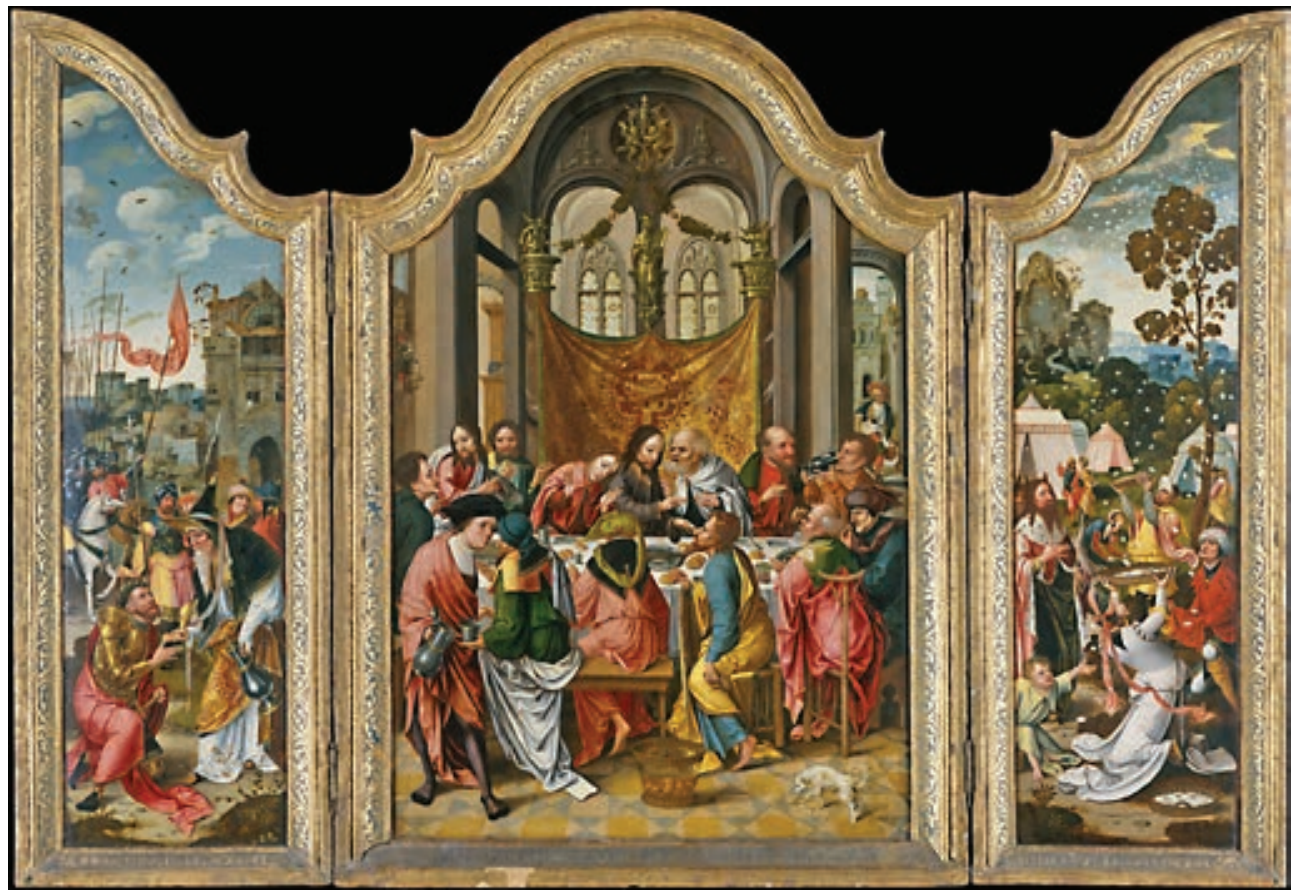

Илл. 120. Антверпенский маньерист. Триптих «Тайная вечеря». Ок. 1515-1520. Музей Метрополитен, Нью-Йорк

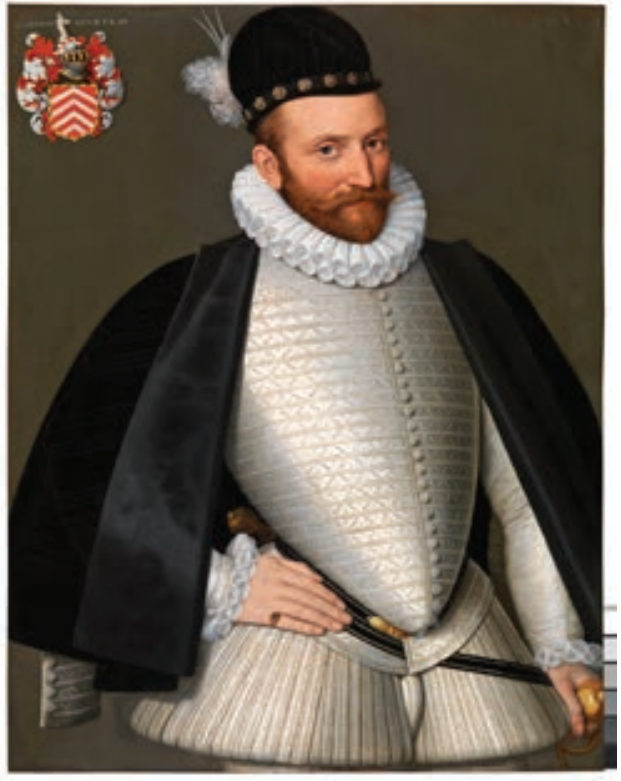

Илл. 121. Гиллис Клаиссенс. Портрет Йориса Ван Бракеле. Ок. 1575 г. Частное собрание

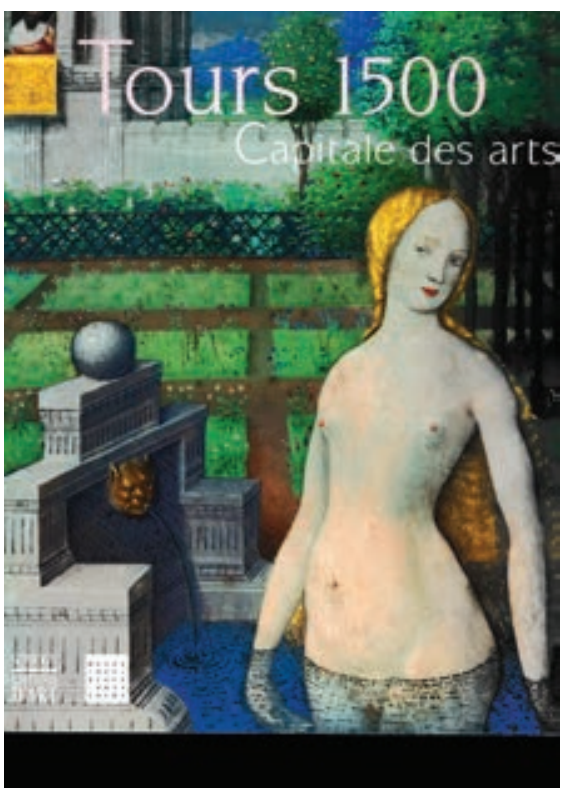

Ill. 122. Front cover of the catalog of exhibition Tours 1500, capital des arts, Tours, Museum of Fine Arts, March $17^{\text {th }}-$ June $17^{\text {th }} 2012$ 


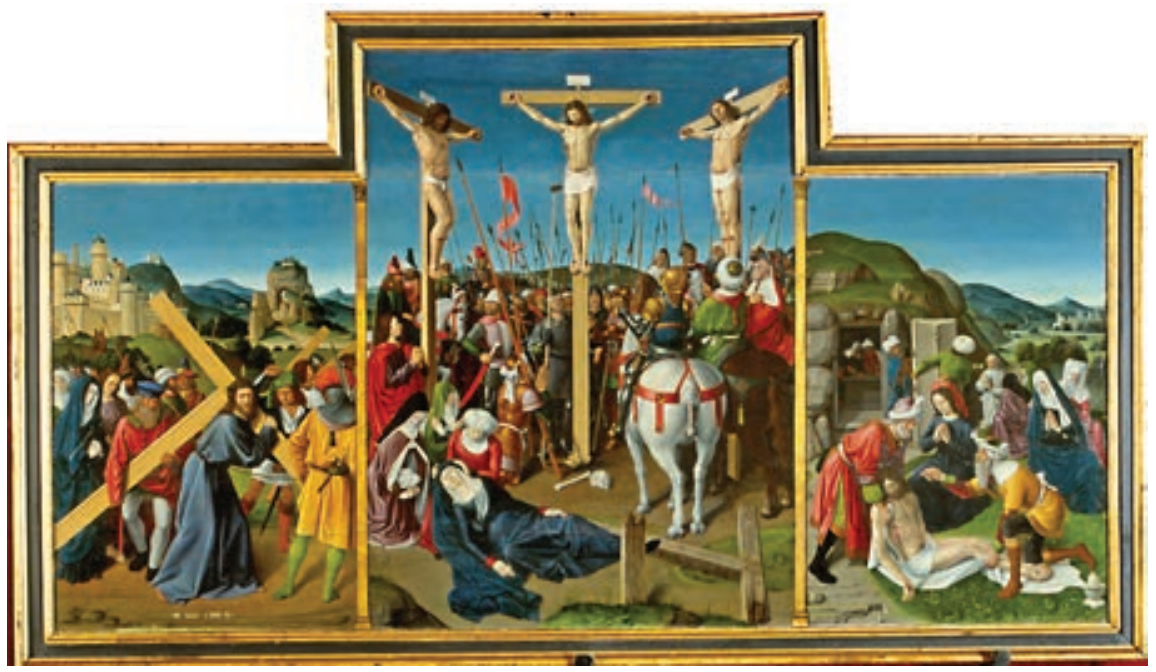

Ill. 123. Jean Poyer. Liget Altarpiece. Loches, Galerie Antonine, France. () P. Charron

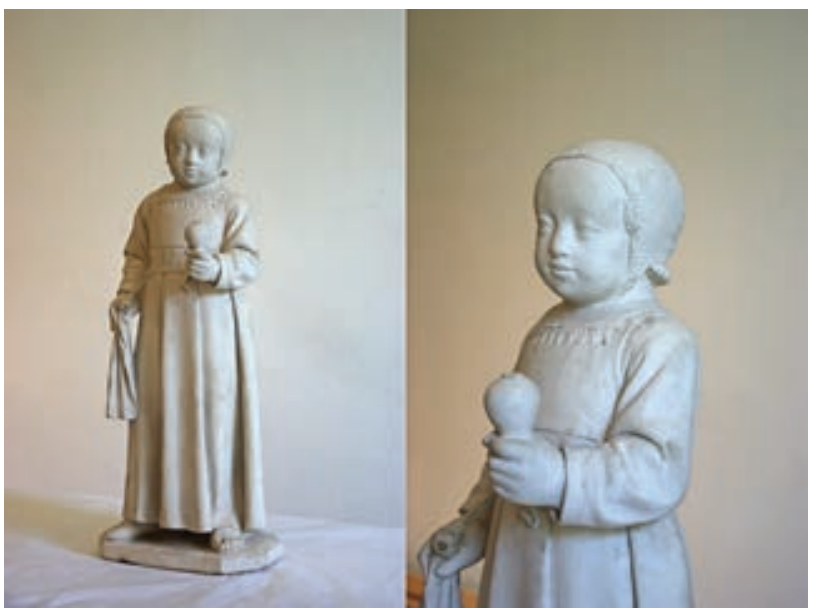

Ill. 124. Saint Cyr as a child (?). Jarzé church, Maine-et-Loire, France. (C) P. Charron

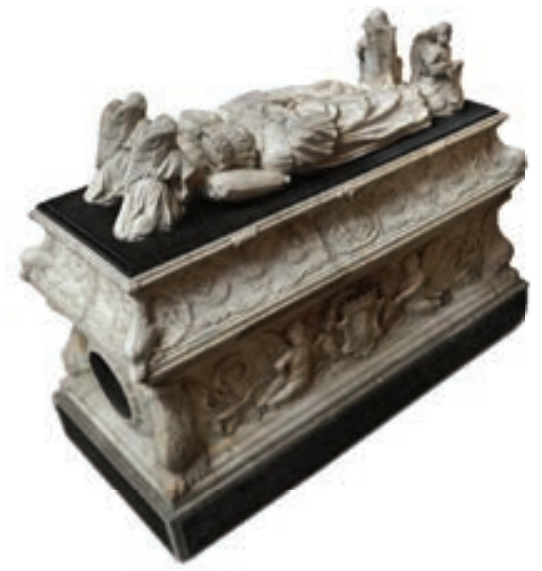

Ill. 125. Textured 3-Dimensional model of the Charles VIII's children tomb. Tours Cathedral, France. (c) G. Venturini 


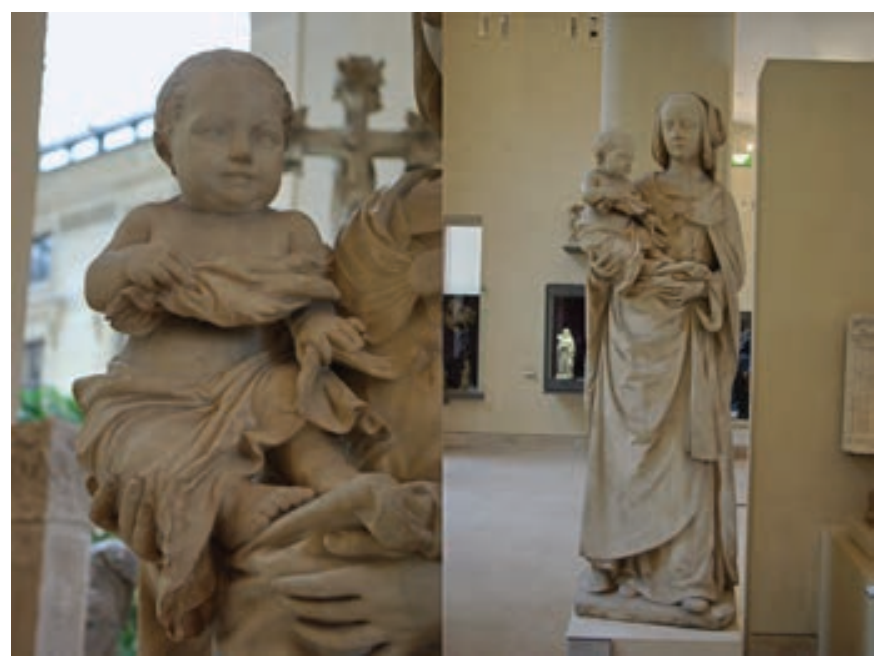

Ill. 126. Guillaume

Regnault workshop.

Virgin and Child. Paris,

Musée du Louvre,

France.

(C) M. Boudon-Machuel

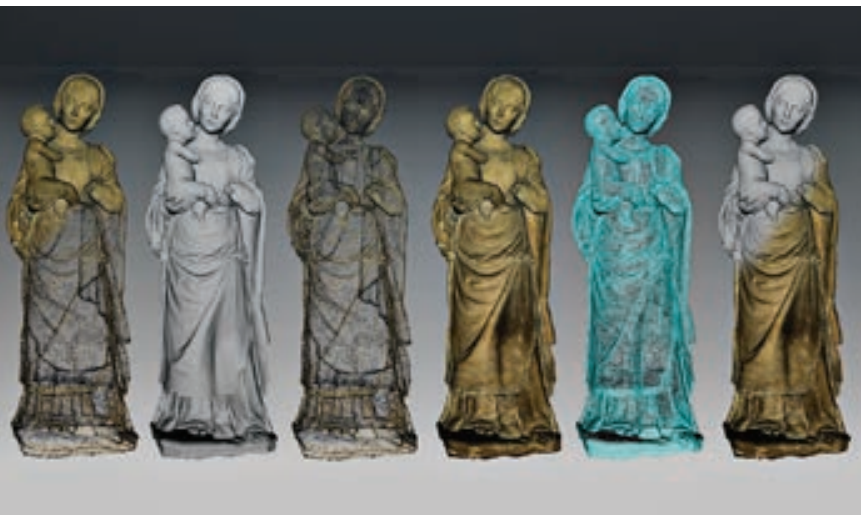

Ill. 127. Multiples rendering methods (wireframe, textured) from the 3-Dimensional model of the Virgin and Child. Blois, Château-Musée, France. (c) G. Venturini

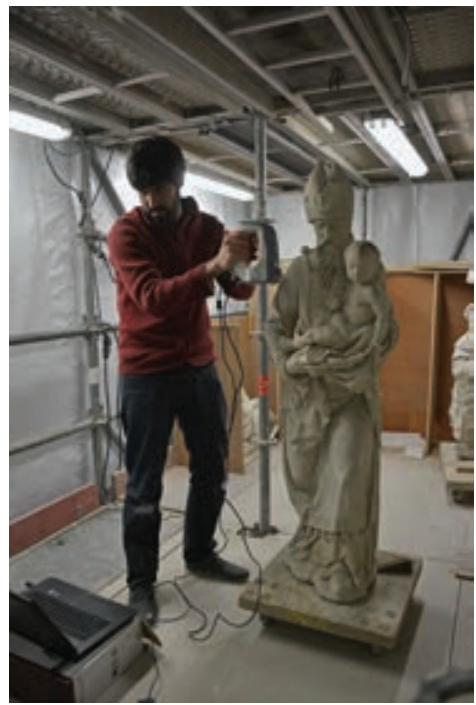

Ill. 128. 3D

scan setup of The High Priest with Jesus Child of Chartres,

France.

(C) M. BoudonMachuel

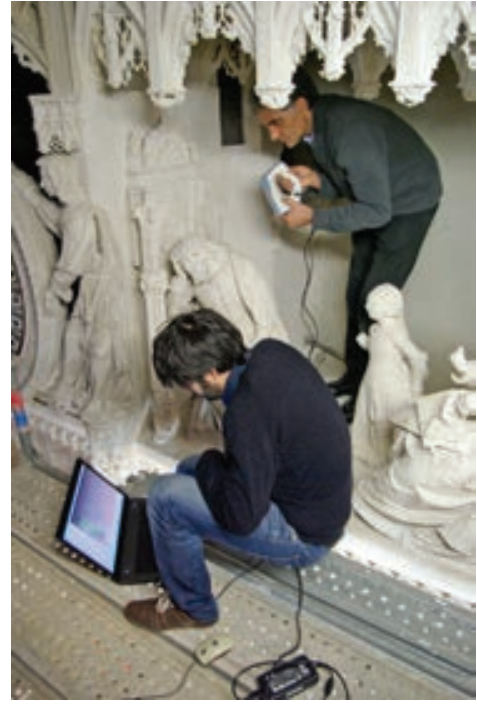

Ill. 129.

"Sculpture 3D" team in Chartres Choir, France. (c) M. BoudonMachuel 